\title{
Callyspongia crassa and C. siphonella (Porifera, Callyspongiidae) as a potential source for medical bioactive substances, Aqaba Gulf, Red Sea, Egypt
}

Hassan A. H. Ibrahim¹, Hussein A. El-Naggar 2*, Khalied A. El-Damhougy², Mansour A. E. Bashar² and Fekry M. Abou Senna²

\begin{abstract}
Background: Sponges are champion of bioactive producers because of the variety of products that have been found from them. Most bioactive compounds extracted from sponges were classified into antibiotic, antiviral, antitumor, and anti-inflammatory. Tow marine sponge species were collected during winter 2016 from Gulf of Aqaba, Red Sea, Egypt viz., Callyspongia crassa and Callyspongia siphonella. The collected sponge species belong to family Callyspongiidae. The sponge samples were extracted by ethanol and investigated as a promising source of natural products which can be used as antitumor, antiviral, and antimicrobial, antioxidant, and anti-inflammatory agents.

Results: Results revealed that the crude extract of C. siphonella showed high antitumor activity with value of 5.57 and $1.39 \mathrm{\mu g} / \mathrm{ml}$ as IC50 against colon cancer (caco-2) and breast cancer (Mcf-7) on cell line, respectively. Also the C. crassa extract showed high cytotoxic effect to Vero cell with HAV (hepatitis A virus), which exhibits that MIC was $9.765 \mu \mathrm{g} / \mathrm{ml}$, the most effective extract was of C. crassa against Escherichia coli, Pseudomonas aeruginosa, and Candida albicans. Also, ethanolic crude of $C$. siphonella showed positive antibacterial activity against $P$. aueroginosa. Indeed, there much other extracts exhibited no antibacterial activities, especially all extracts against Staphylococcus aureus and Vibrio damsela. The C. crassa extract conducted an antioxidant activity in corresponding to ascorbic acid standard with value of $671 \mu \mathrm{g} / \mathrm{ml}$ as IC50. There was only one crude extract that had anti-inflammatory activity; it was of C. crassa (61.47\%).
\end{abstract}

Conclusions: The present investigation confirmed that the crude extract of $C$. siphonella conducted to promising antitumor agent against colon and breast cancer, while the crude extract of C. crassa conducted to promising anti-inflammatory and antiviral agents. In summary, the marine sponges are an indispensable, chemodiverse, biodiverse, and rich source of natural products and secondary metabolites with potent pharmacological effects. The studies should be interested with spongederived bioactive compounds as a promising strategy that deserves further attention in future investigations in order to address the limitations regarding sustainable supply of marine drugs.

Keywords: Sponges, Red Sea, Antitumor, Antiviral, Antimicrobial, Anti-inflammatory

\footnotetext{
* Correspondence: Hu_gar2000@yahoo.com

${ }^{2}$ Faculty of Science, Al-Azhar University, Cairo, Egypt

Full list of author information is available at the end of the article
} 


\section{Background}

Marine organisms are rich source of structurally novel and biologically active metabolites. Some studies have suggested that some bioactive compounds isolated from marine organisms have been shown to have anticancer, anthelmintic, antibacterial, antifungal, antiviral, antimalarial, anticoagulant, antiprotozoal, antituberculosis, or anti-inflammatory and other pharmacological activities (Mayer and Hamann 2005; Blunt et al. 2005; Somnath and Ghosh 2010). Many bioactive compounds have been obtained from various marine animals like sea hares, nudibranchs, bryozoans, tunicates, sponges, soft corals, sea slugs and marine microorganisms, etc (Donia and Hamann 2003). Among marine invertebrates, Porifera (sponges) remain the most prolific phylum, concerning novel pharmacologically active compounds (Faulkner 2000). Richter (1907) outlined that the active component of the roasted bath sponge, used by Roger against Struma, is iodine. The work on sponge natural products was systematically started by who isolated three nucleosides from the Caribbean sponge Cryptotethyacrypta laubenfels. Antiviral properties of these nucleosides were demonstrated later (Privat et al. 1964) and initiated the synthesis of analogues which led to the first antiviral compound Ara-A (active against herpes virus) and antitumor compound Ara-C (effective in acute lymphoid leukemia). The compounds Ara-A and Ara-C are the only marine invertebrate-related compounds in clinical use (Guyot 2000). Arabinosyl Cytosine (Ara-C) is currently sold by the Pharmacia \& Upjohn Company under the brand name Cytosar-UR. Since this pioneering work, number of novel bioactive molecules have been discovered from this group, which include cytotoxins, antibiotics, antiviral, and anti-inflammatory compounds. It is known that sponges the most diverse marine invertebrates have evolved antagonistic effects against other invading organisms, which involves the production of the secondary metabolites (Wah et al. 2006). The secondary metabolites isolated from marine sponges may be alternative source for vector control agents to replace existing and highly toxic synthetic insecticides and will play an important role in future insecticide development program (Rao et al. 2008). Initial experimental results suggested that sponges have the potential to provide future drugs against important diseases, such as cancer, a range of viral diseases, malaria, and inflammations (Perdicaris et al. 2013). Also, some of the most potential spongederived bioactive molecules include the anti-inflammatory compound Manolide from the Palauan sponge Luffariella variabilis (De-Silva and Scheuer 1980), the immunosuppressive and cytotoxic compound Discodermolide from the deep sea sponge Discodermia dissolute (Gunasekera et al. 1990), anti-angiogenic brominated compound aeroplysina1 from a sponge Aplysina aerophoba (Rodriguez-Nieto et al. 2002), tubulin polymerizing compound dictyostatin-1, a polyketide from Spongia sp. (Isbrucker et al. 2003) etc.
Therefore, the present study aims to extract bioactive substances from marine sponges species inhabiting Gulf of Aqaba, Red Sea, Egypt in a hope to be used as potential medical agents in several applications (such as; antiviral, antimicrobial, antioxidant, antitumor, and anti-inflammatory).

\section{Methods}

Sampling and identification of sponge specimens

The investigated specimens were collected during winter 2016 at different depths along Gulf of Aqaba by SCUBA diving. The identification of all specimens has been carefully checked on the basis of morphological characters according to Systema Porifera (Hooper and Van Soest 2002) and the recent update undertaken in the World Porifera Database (Van Soest et al. 2008).

\section{Preparation of different sponge crude extracts}

One hundred grams of each marine sponge specimen were macerated with $200 \mathrm{ml}$ of $70 \%$ aqueous ethanol. After soaking for a week with genital shaking, they were filtered through Whatman 542 filter paper. Solvent was evaporated using rotary evaporator to obtain soluble extracts (Ballantine et al. 1987).

\section{Antimicrobial assay \\ Microbial indicator strains}

The bacterial indicators were Escherichia coli, Pseudomonas aeruginosa, Staphylococcus aureus, Vibrio damsela, and Candida albicans.

\section{Media and bacterial cultures}

Nutrient broth (Atlas 1997): composed of $\left(\mathrm{gl}^{-1}\right)$ the following: yeast extract, 2; beef extract, 1; peptone, 5; sodium chloride, 5. Agar (15-20) was added for obtaining nutrient agar. All bacterial pathogenic strains were maintained on nutrient agar slants. Bacterial inoculate were prepared by inoculating $100 \mathrm{ml}$ of nutrient broth medium, and incubated shaken $(250 \mathrm{rpm})$ at $30{ }^{\circ} \mathrm{C}$ for $24 \mathrm{~h}$ until late logarithmic phase of growth $\left(A_{550}=1\right)$. Antibacterial activity was carried out on nutrient agar plates.

\section{Antimicrobial activity of sponge crude extracts}

The well-cut diffusion technique was used to test the ability of the crude extracts of sponges to inhibit the growth of indicator bacteria and Candida. One hundred microliters of the tested crude extracts were transferred into each inoculated well after sterilizing by ultra-filtration. All plates were incubated at appropriate temperature for 24-48 h. After incubation period, the radius of clear zone around each well $(\mathrm{Y})$ and the radius of the well $(\mathrm{X})$ were linearly measured in $\mathrm{mm}$, where dividing $\mathrm{Y}^{2}$ over $\mathrm{X}^{2}$ determines an absolute unit (AU) for the clear zone. The absolute unit of crude extract, 
which indicates a positive result, was calculated according to the equation (Yang et al. 1992):

$$
\mathrm{AU}=\mathrm{Y}^{2} \pi / \mathrm{X}^{2} \pi
$$

\section{Antitumor assay}

Cultures were viewed using an inverted microscope to assess the degree of confluence and the absence of bacterial and fungal contamination. Crude extracts of sponge were tested for any cytotoxic activity against two tumor cell lines. They were caco-2 (colon cancer) and Mcf-7 (breast cancer). When the cells grown on $75 \mathrm{~cm}^{2}$ tissue culture flasks reached confluence (usually $24 \mathrm{~h}$ ), the cell suspension of the three tumor cell lines were prepared in complete growth medium (DMEM). The aliquots of $(100 \mu \mathrm{l})$ of cell suspension were added to each well on a 96-well tissue culture plate. The blank wells contained medium in place of cell suspension. The cells were incubated for $24 \mathrm{~h}$ at $37{ }^{\circ} \mathrm{C}$ in humidified atmosphere of $5 \%$ $\mathrm{CO}_{2}$. After the formation of a complete monolayer cell sheet in each well of the plate, the medium was aspirated and replaced with DMEM with $2 \%$ fetal bovine serum. Then, the extracts were dispensed into 96-tissue culture plate at $50 \mu \mathrm{l} /$ well. Another set of well was kept for including wells of cell controls in which $(50 \mu \mathrm{l})$ of DMEM with $2 \%$ FBS being added instead of the extracts as negative control. Serial three fold dilutions of the plant extract were added into a 96-well sterile tissue culture plate using multichannel pipette. The treated and untreated cells were covered with a plate sealer then allowed to grow and proliferate by further incubation the plate for $24 \mathrm{~h}$ at $37^{\circ} \mathrm{C}$ in humidified atmosphere of $5 \% \mathrm{CO}_{2}$. At the end of incubation, the plate was examined using the inverted microscope.

The number of survival cells was determined by staining with crystal violet. Briefly, after the end of incubation period, the plate containing the treated and untreated cells were inverted or aspirated to remove the medium. Then, the wells were washed by $100 \mu \mathrm{l}$ of PBS and then the cells were fixed with $10 \%$ formalin for $15 \mathrm{~min}$ at room temperature. The cells were then stained with $100 \mu \mathrm{l}$ of crystal violet for $20 \mathrm{~min}$. The excess of stain was removed, and the plates were rinsed with deionized water and then dried. The cellular morphology was observed by using inverted microscope with digital camera to capture the images representing the morphological changes in the treated cells compared with control cells. To obtain quantitative data, the dye was extracted from the cells by adding glacial acetic acid (33\%) to each well and mixed the contents of each well before reading the absorbance on the ELISA reader (SunRise TECAN, Inc. ${ }^{\circ}$, USA) at $490 \mathrm{~nm}$. The absorbance is proportional to the number of survival cells in the culture plate (Saintigny et al. 2011).
The percentage cell viability was calculated using the Microsoft Excel ${ }^{\circ}$. Percentage cell viability was calculated as follows:

$$
\begin{aligned}
& \text { Cell viability } \%= \text { Mean Abs control-Mean Abs plant extract } \\
& \times 100
\end{aligned}
$$

Mean Abs control, where Abs absorbance at $490 \mathrm{~nm}$

\section{Antiviral assay}

Vero cells used in the present study were established by Yasumura and Kawakita 1963. Vero cell line was developed for isolation and propagation of many entero viruses and hepatitis A. In the current study, Vero cells from passage number 76 were grown and maintained in Dulbecco's modified Eagle's medium (DMEM) with Hanks salt base, supplemented with $10 \%$ fetal calf serum and $50 \mu \mathrm{g} / \mathrm{ml}$ gentamycin antibiotic solution. Rapidly growing virus strains producing cytopathic effect (CPE) in vero cell cultures within 3 days was used during this study. This virus was hepatitis A virus $\mathrm{H}-10$ strain which isolated by Ali and Abdel Wahab in 1991.

Cytotoxicity of crude extracts of sponges were determined through morphological changes in Vero cells treated with different extracts in comparison with untreated control one. While antiproliferative activity was measured using MTT assay. The MTT kit was based on dehydrogenase in a viable cell to determine cell viability with colorimetric method that reduced the coloring reagent. Vero cells were grown as monolayer in media supplemented with $10 \%$ inactivated fetal bovine serum. The monolayers of $(10,000)$ cells were plated $\left(10^{4}\right.$ cells/well $)$ in 96 -well tissue culture plate and were incubated for $24 \mathrm{~h}$ at $37{ }^{\circ} \mathrm{C}$ in a humidified incubator with $5 \% \mathrm{CO}_{2}$ before treatment with the extracts to allow attachment of cell to the plate except three well without cells as blank. Different concentrations of crude extracts of sponges $(100,50,25,12.5,6.25,3.125,1.56,0.78$, and $0 \mu \mathrm{g} / \mathrm{l})$ were added to the cell monolayer. Triplicate wells were prepared for each concentration except another three wells without extract as negative control. The plates were incubated for $48 \mathrm{~h}$ into $\mathrm{CO}_{2}$ incubator at $37{ }^{\circ} \mathrm{C}$ and $5 \% \mathrm{CO}_{2}$. After $48 \mathrm{~h}$, the cells were observed under inverted microscope before completing the assay to observe the difference in morphology between cell controls and treated one at different concentrations of tested substances. The cell culture media containing different concentrations of tested extracts and dead cells was decanted, and viable attached cells into the tissue culture plate were leaved. The plate containing viable cells was washed twice with PBS. Fifty microliters of MTT reagent was added to each well including blank and negative control wells. After addition of MTT reagent, the plates were incubated in the dark for $4 \mathrm{~h}$ for the reduction of MTT into formazan (purple needle color) by dehydrogenase activity in mitochondria of viable cells. One hundred microliters of DMSO was added to each well to 
solubilize the purple crystals of formazan. Absorbance was measured at $(570 \mathrm{~nm})$ with microplate reader. The maximum nontoxic concentration (MNTC) was determined. The percentage of cell survival was calculated by the following equation:

$$
\text { Survival rate } \%=\frac{\mathrm{A} \text { sample }-\mathrm{Ab}}{\mathrm{Ac}-\mathrm{Ab}} \times 100
$$

Where $\mathrm{Ac}=$ negative control, $\mathrm{Ab}=$ blank

\section{Antioxidant assay}

The antioxidant activity of extract was determined by the 2, 2-diphenyl-1-picrylhydrazyl (DPPH) for free radical scavenging assay in triplicate and average values were considered. Freshly prepared $(0.004 \% ; w / v)$ methanol solution of DPPH radical was prepared and stored at $10{ }^{\circ} \mathrm{C}$ in the dark. The tested compound was prepared. A $40 \mu \mathrm{l}$ aliquot of the tested extract was added to $3 \mathrm{ml}$ of DPPH solution. Absorbance measurements were recorded immediately with a UV-visible spectrophotometer (Milton Roy, Spectronic 1201). The decrease in absorbance at $(515 \mathrm{~nm})$ was determined continuously, with data being recorded at $1 \mathrm{~min}$ intervals until the absorbance stabilized (16 min). The absorbance of DPPH radical without antioxidant (control) and the reference compound ascorbic acid were also measured. All the determinations were performed in three replicates and averaged. The percentage inhibition (PI) of the DPPH radical was calculated according to the following formula:

$$
\mathrm{PI}=[\{(\mathrm{AC}-\mathrm{AT}) / \mathrm{AC}\} \times 100]
$$

Where $\mathrm{AC}=$ absorbance of control at $t=0 \mathrm{~min}$ and $\mathrm{AT}=$ absorbance of the sample $+\mathrm{DPPH}$ at $t=16 \mathrm{~min}$ (Yen and Duh 1994).

\section{Anti-inflammatory assay}

Screening for the anti-inflammatory producers carried out by using the simple economical assay; in vitro inhibition of protein (albumin) denaturation technique (Sakat et al. 2010). Test solution $(2500 \mu \mathrm{l})$ consisted of $2250 \mu \mathrm{l}$ of bovine serum albumin (BSA) (1\%, $w / v$ aqueous solution) and $250 \mu \mathrm{l}$ of test solution (supernatant of the culture) was prepared. Test control solution consisted of $2250 \mu \mathrm{l}$ of bovine serum albumin (BSA) and $250 \mu$ of blank broth was prepared. Standard solution consisted of $2250 \mu \mathrm{l}$ of bovine serum albumin (BSA) and $250 \mu \mathrm{l}$ of Diclofenac sodium "Voltaren" ampoule Novartis Pharma" (100, 250, 500 , and $1000 \mu \mathrm{g} / \mathrm{ml}$ ) was prepared. All of the previous solutions were adjusted to $\mathrm{pH} 5.5$ using a small amount of $0.1 \mathrm{~N} \mathrm{HCl}$, and or $0.1 \mathrm{~N} \mathrm{NaOH}$. The samples were incubated at $37{ }^{\circ} \mathrm{C}$ for $20 \mathrm{~min}$ and then transferred to $60{ }^{\circ} \mathrm{C}$ water bath for $5 \mathrm{~min}$. The samples at room temperature were cooled then $2500 \mu \mathrm{l}$ of phosphate buffer were added to the above solutions. The absorbance of the above solutions was measured using UV-Visible spectrophotometer at $660 \mathrm{~nm}$. The percentage inhibition of protein denaturation was calculated using the following formula:

$$
\begin{aligned}
& \text { Inhibition of protein denaturation }(\%) \\
& \qquad=\left(\frac{\text { absorption of control-absorption of test }}{\text { absorption of control }}\right) \times 100
\end{aligned}
$$

The control represents $0 \%$ inhibition of protein denaturation. The activity of each tested supernatant was compared with the standard commercial anti-inflammatory agent "Diclofenac sodium" using different concentrations $(100,250,500$, and $1000 \mu \mathrm{g} / \mathrm{ml})$.

\section{Results \\ Sponge identification}

Table 1 and Fig. 1 proved the taxonomical position of collected sponges in the animal kingdom. However, they were Callyspongia crassa and Callyspongia (Siphonochalina) siphonella.

C. crassa (Keller, 1889) has shape like a large brown tube to an average diameter of $30 \mathrm{~cm}$ characterized by spines covering substantially its entire surface with the exception of a strip of $10 \mathrm{~cm}$ in the upper part around the whole tube.

C. siphonella (Levi, 1965) showed as a cluster of vertical tubes from a common base. These tubes can reach $60 \mathrm{~cm}$ in height and have smooth consistency due to the absence of spicules. Its color is usually pale purple or pink or reddish-brown.

The two identified sponge species were screened as a potential source for bioactive substances. So, antibacterial, antiviral, antioxidant, antitumor, and anti-inflammatory activities were detected.

Table 1 Scientific classification of the sponge samples collected from Gulf of Aqaba

\begin{tabular}{lll}
\hline \multirow{2}{*}{$\begin{array}{l}\text { Scientific } \\
\text { Classification }\end{array}$} & Sponge sample & \\
\cline { 2 - 3 } Kingdom & Callyspongia crassa & Callyspongia siphonella \\
Phylum & Animalia & Animalia \\
Class & Porifera & Porifera \\
Order & Demospongiae & Demospongiae \\
Family & Haplosclerida & Haplosclerida \\
Genus & Callyspongiidae & Callyspongiidae \\
Species & Callyspongia & Callyspongia \\
Common Name & Callyspongia crassa & Callyspongia siphonella \\
\hline
\end{tabular}




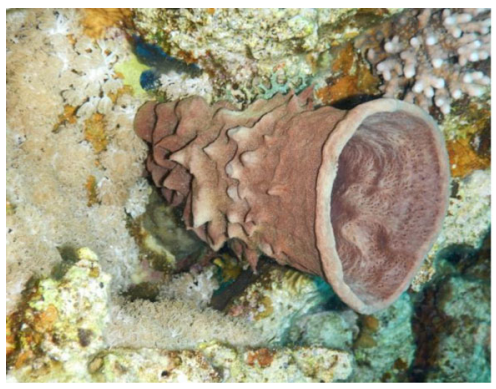

Callyspongia crassa (Keller, 1889)

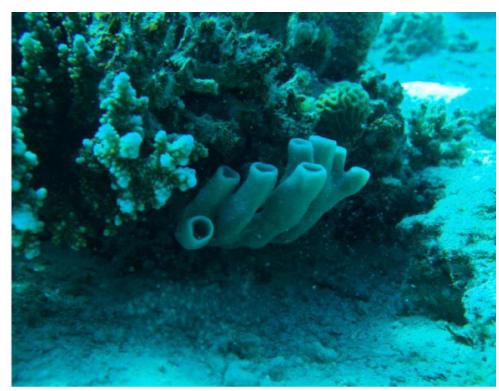

Callyspongia siphonella (Levi, 1965)

Fig. 1 The two investigated sponge species

\section{Antitumor activity of crude sponge extracts}

Data shown in Fig. 2 revealed that the crude extract of $C$. crassa showed antitumor activity with value of $13.05 \mu \mathrm{g} / \mathrm{ml}$ as IC50 which able to kill the half number of tumor cells of caco-2. While C. siphonella extract showed antitumor activity with value of $5.57 \mu \mathrm{g} / \mathrm{ml}$ as IC50 which able to kill the most number of tumor cells of caco-2. This experiment showed a very strong activity of two extracts against colon cancer cells.

On the other side, the same crude extract of C. crassa showed antitumor activity on Mcf-7 cell line with value of $9.47 \mu \mathrm{g} / \mathrm{ml}$ as IC50 which able to kill the more number of tumor cells of Mcf-7 (Fig. 3). While C. siphonella extract showed antitumor activity with value of $1.39 \mu \mathrm{g} / \mathrm{ml}$ as IC50 which able to kill about most number of tumor cells of Mcf-7. This experiment declared a very strong activity of two extracts against breast cancer cells.

\section{Antiviral activity of crude sponge extracts}

The C. crassa extract showed cytotoxic effect to Vero cell in all dilutions except the last three ones; cytotoxic effect of C. crassa on Vero exhibits that MIC is $9.765 \mu \mathrm{g} / \mathrm{ml}$, also the incubation period increases the effect of extract on Vero cell. Finally, MNTC was detected as $4.882 \mu \mathrm{g} / \mathrm{ml}$ for further studies by MTT assay (Fig. 4). The C. siphonella extract showed cytotoxic effect to Vero cell in all dilutions except the last two ones; cytotoxic effect of C. siphonella on Vero exhibits that MIC was $0.625 \mu \mathrm{g} / \mathrm{ml}$, also the incubation period increases the effect of extract on Vero cell. MNTC was detected as $0.312 \mu \mathrm{g} / \mathrm{ml}$ for C. siphonella for further studies by MTT assay.

The maximum non-toxic concentrations of both extracts (C. crassa and C. siphonella) were 4.9 and $0.3 \mu \mathrm{g} / \mathrm{ml}$, respectively). They subsequently investigated to evaluate their potential against HAV, so, according to method applied, HAV was injected to Vero cell causing toxicity for 60.5 of Vero cell which represents $100 \%$ of its actual virulent power. By application of C. crassa crude extract, the toxicity of virus to vero cell became 5.6 which represent $14.7 \%$ of viral activity so, $C$. crassa crude extract exhibited antiviral activity of $85.3 \%$ while, by using C. siphonella crude extract, the toxicity of virus to vero cell became 50.6 which represent $83.7 \%$ of viral activity, so, C. siphonella crude extract exhibited antiviral activity in percentage of $16.4 \%$.

Entirely, both C. crassa and C. siphonella showed antiviral against HAV under the experimental conditions, but $C$. crassa showed a relatively higher activity than C. siphonella.

\section{Antimicrobial activity of crude sponge extracts}

The antimicrobial activity produced by different crude extracts of sponge species was screened against several human

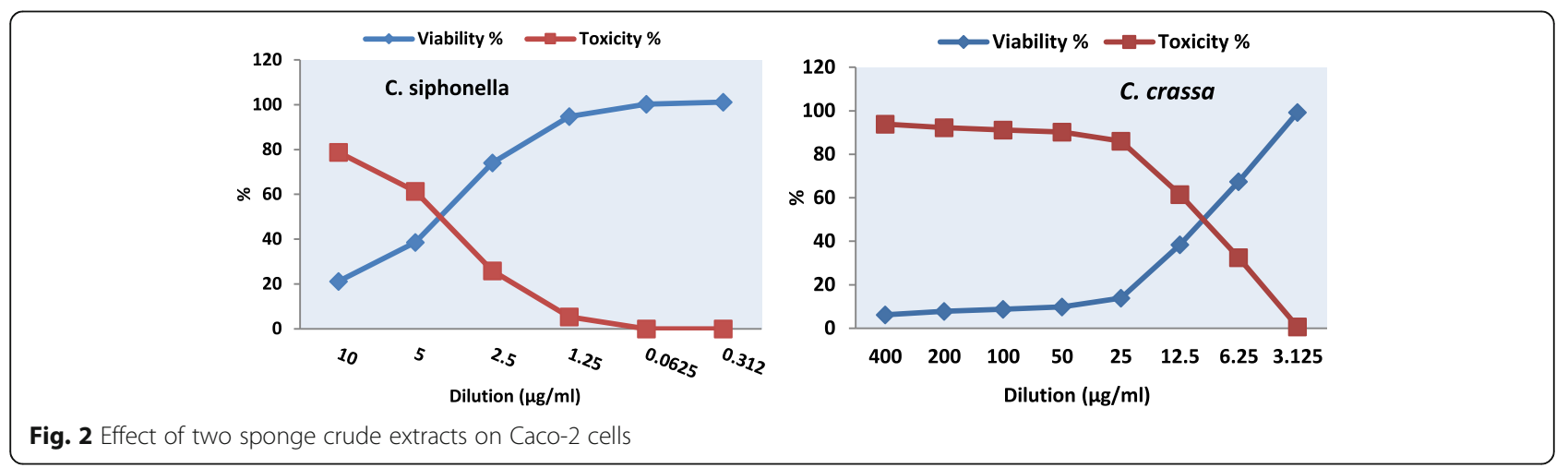



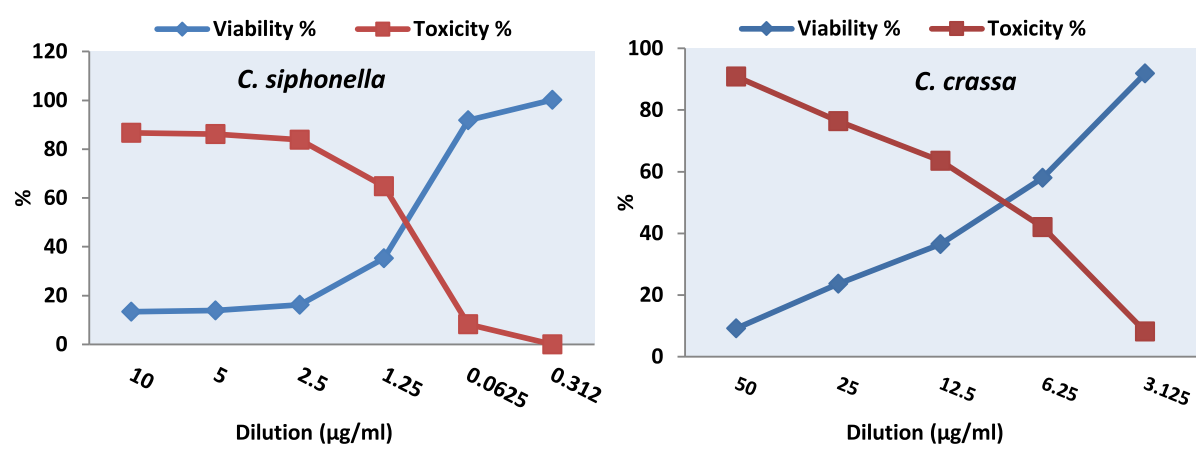

Fig. 3 Effect of two sponge crude extracts on Mcf-7 cells

and fish pathogens (E. coli, P. aeruginosa ATCC8739, S. aureus ATCC6538, V. damsela, and C. albicans).

The results showed antimicrobial activity against one or more of the test organisms. Data shown in Table 2 revealed that the most effective extract was of $C$. crassa against E. coli, P. aueroginosa and C. albicans. Also, ethanolic crude of $C$. siphonella showed positive antibacterial activity against $P$. aueroginosa.

\section{Antioxidant activity of crude sponge extracts}

Data in Table 3 showed that C. crassa extract conducted an antioxidant activity in corresponding to ascorbic acid standard with value of $671 \mu \mathrm{g} / \mathrm{ml}$ as IC50 and by the same way the extracts of $C$. siphonella had no any antioxidant activity at any dilutions. The C crassa extract showed an antioxidant activity, but their IC50 value was larger than IC50 which belongs to ascorbic acid and that means the antioxidant power of ascorbic acid is larger than this sample.

\section{Anti-inflammatory activity of sponge crude extracts}

The ethanolic crude extracts of the investigated sponge species were examined as anti-inflammatory agents. Table 4 exhibited that there was only one crude extract that had anti-inflammatory activity; it was of C. crassa (61.47\%). Data revealed that the crude extract of $C$. crassa conducted to promising anti-inflammatory agent. The extract of $C$. siphonella had no any anti-inflammatory activity at all.

\section{Discussion}

The collected sponge species screened in this study are Callyspongia crassa and Callyspongia (Siphonochalina) siphonella. Unfortunately, sponges are often ignored within large-scale surveys due to problems associated with the availability of taxonomic expertise, although recent texts are addressing these problems (e.g., Hooper and Van Soest 2002). Callyspongia crassa was collected from Abu galum (Al-dahyla) site at depth $15-25 \mathrm{~m}$, previously; Kelman et al. (2000) detected this species in the northern Red Sea Gulf of Aqaba at Eilat from 1 to $30 \mathrm{~m}$ depth.

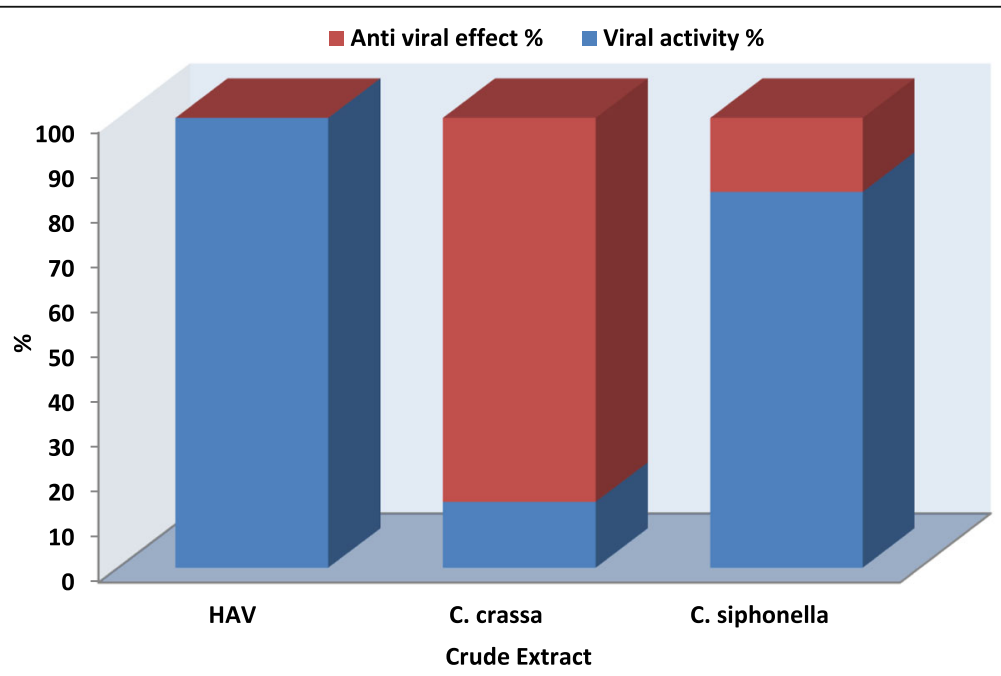

Fig. 4 Antiviral activity of crude sponge extracts against HAV 
Table 2 Antimicrobial activity of sponge crude extracts

\begin{tabular}{llllll}
\hline Crude extract & E. coli & P. aueroginosa & S. aureus & V. damsela & C. albicans \\
\hline C. crassa & +ve & tve & $-v e$ & $-v e$ & $+v e$ \\
C. siphonella & $-\mathrm{ve}$ & $+\mathrm{ve}$ & $-\mathrm{ve}$ & $-\mathrm{ve}$ & $-\mathrm{ve}$ \\
\hline
\end{tabular}

On the other hand, Callyspongia (Siphonochalina) siphonella was collected from Dahab (Canyon) at depth of 10-35 m. Kelman et al. (2000) and Ilan et al. (2004) explored it in deeper water from 1 to $30 \mathrm{~m}$ depth at Eilat coast, Gulf of Aqaba. Also, Gab-Alla et al. (2000) found it in Ras Um EI Sied site at Sharm El-Sheikh, Gulf of Aqaba.

Perdicaris (Perdicaris et al. 2013) stated that marine sponges (Porifera) have been ranked very high in the priority of natural product research because the discovery of a wide range of bioactive chemical components and secondary metabolites with potential pharmaceutical applications gave promising results. Therefore, they have the potential to provide future treatment against important diseases, such as cancer, a range of viral diseases, and inflammations (Faulkner 2000; Perdicaris et al. 2013). So, the present investigation aims to screen two species of sponge collected from Gulf of Aqaba, Red Sea, Egypt as a source of bioactive substances which can be used as antimicrobial, antiviral, antitumor, antioxidant, and anti-inflammatory agents.

Results obtained during this study revealed that the crude extract of C. siphonella showed the highest antitumor activity with value of 5.57 and $1.39 \mu \mathrm{g} / \mathrm{ml}$ as IC50 against colon cancer (caco-2) and breast cancer (Mcf-7) on cell line, respectively.

The sponge crude extracts seems to have effective cytotoxic property that was detected by Brine shrimp assay. Sponges of the class Demospongiae are known to produce the largest number and diversity of secondary metabolites isolated from marine invertebrates; most of them with medically relevant biological activities and important ecological roles (Faulkner 2002). The toxicity of sponges has been well-documented, which could be ascribed to the diverse and potent cytotoxic compounds (Lee and Qian 2003).

Recently, scientists purified a lectin from the marine sponge Cinachyrella apion (CaL) that was evaluated with respect to its hemolytic, cytotoxic, and antiproliferative properties, besides the ability to induce cell death in tumor cells. Results showed that the lectin induces cell death by

Table 3 DPPH \% of different sponge crude extracts

\begin{tabular}{llllllll}
\hline Extract & \multicolumn{7}{l}{ Concentration $(\mu \mathrm{g} / \mathrm{ml})$} \\
\cline { 2 - 8 } & 0 & 25 & 50 & 100 & 200 & 400 & 800 \\
\hline Ascorbic acid & 0.0 & 77.41 & 93.6 & 100 & 100 & 100 & 100 \\
C. crassa & 0.0 & 3.5 & 11.7 & 17.7 & 21.1 & 32.9 & 58.1 \\
S. siphonella & 0.0 & 0.0 & 0.0 & 0.0 & 0.0 & 0.0 & 0.0 \\
\hline
\end{tabular}

Table 4 Anti-inflammatory activity of different sponge crude extracts

\begin{tabular}{lll}
\hline Sponge crude extract & $\begin{array}{l}\text { \% inhibition of protein } \\
\text { denaturation }\end{array}$ & $\begin{array}{l}\text { Anti-inflammatory } \\
(\%)\end{array}$ \\
\hline Blank & 0.00 & 0.00 \\
C. crassa & 61.47 & 61.47 \\
S. siphonella & -69.72 & 0.00 \\
\hline
\end{tabular}

apoptosis activation by pro-apoptotic protein Bax, promoting mitochondrial membrane permeabilization, cell cycle arrest in $\mathrm{S}$ phase and acting as both dependent and/or independent of caspases pathway. These results indicate the potential of $\mathrm{CaL}$ in medical studies for treating cancer (Valeriote et al. 2012).

Another component form sponges that attracted the interest of scientists as an antitumor agent was Heteronemin, a marine sesterterpene isolated from the sponge Hyrtios sp., especially for its biological effects on chronic myelogenous leukemia cells. Results showed that Heteronemin was affecting cellular processes including cell cycle, apoptosis, mitogen-activated protein kinases (MAPKs) pathway, and the nuclear factor kappaB (NF-kappaB) signaling cascade. This compound has potential as anti-inflammatory and anticancer agent (Rabelo et al. 2012).

The present extract of $C$. crassa exhibited high cytotoxic effect to Vero cell with HAV; which exhibits that MIC was $9.765 \mu \mathrm{g} / \mathrm{ml}$. Also C. crassa crude extract exhibited antiviral activity in percentage of $85.3 \%$. Isolation of natural components and metabolites from sponges and screening bioactive substances led to the discovery of numerous chemicals with antiviral properties (Sipkema et al. 2005).

A new norsesterterpene acid, named muqubilone (1), along with the known sigmosceptrellin-B and muqubilin were isolated from the Red Sea sponge Diacarnus erythraeanus. However, Muqubilin 1 showed in vitro antiviral activity against herpes simplex type 1 (HSV-1) with ED50 values of 7.5 and $30 \mu \mathrm{g} / \mathrm{mL}$, respectively. Muqubilin and sigmosceptrellin-B display potent in vitro activity against Toxoplasma gondii at a concentration of $0.1 \mu \mathrm{M}$ without significant toxicity (El-Sayed et al. 2001).

These bioactive molecules are often secondary metabolites, whose main function is to enable and/or modulate cellular communication and defense. They are usually produced by functional enzyme clusters in sponges and/ or their associated symbiotic microorganisms. Several of them have successfully been approved as antiviral agents for clinical use or have been advanced to the late stages of clinical trials. The most important antiviral lead of marine origin reported thus far is nucleoside Ara-A (vidarabine) isolated from sponge Tethya crypta. It inhibits viral DNA polymerase and DNA synthesis of herpes, vaccinica, and varicella zoster viruses (Villa and 
Gerwick 2010). The hepatitis C virus causes chronic infections in humans, which can develop to liver cirrhosis and hepatocellular carcinoma. Recent research on antiviral compounds isolated 128 molecules from marine invertebrates and microorganisms. The best results were obtained from the extracts produced from the Bacillus sp. isolated from the sponge Petromica citrina. These investigated organisms lead to the development of drugs which ensure an alternative therapy for the treatment of hepatitis C (Santiago et al. 2013).

In the recent studies, a number of pure compounds were isolated from marine sponges and were tested in non-toxic concentrations for virus infected cells. Norbatzelladine L isolated from a marine sponge of the genus Monanchora displayed antiviral activity against herpes simplex virus type (HSV-1), with $97 \%$ of inhibition in the viral adsorption phase (Kohn et al. 2012).

Our results indicated that the $C$. crassa extract showed positive antibacterial activity against $E$. coli, $P$. aueroginosa, and C. albicans, while, crude extract of C. siphonella showed positive activity against $P$. aueroginosa. The two extracts against $S$. aureus and $V$. damsel had no antibacterial activities.

Actually, the extracts of a large number of sponges exhibited broad spectrum of antibacterial activity. Some of these extracts were especially active against Staphylococcus, Pseudomonas, acid fast bacteria, and pathogenic yeasts, such as Monila (Sharma et al. 1970).

Abou-Elela et al. (2009) tested crude extracts of marine sponge against different bacterial pathogens by well-cut agar diffusion method. They found that extracts of Spongia officinalis (Alam El Roomat $50 \mathrm{~m}$ ) showed the highest inhibiting activity. Activity units ranged from 4.59 against $S$. aureus, $S$. faecalis, and $P$. aeruginosa to 6.61 against $E$. coli. Also, they observed that chloroform crude extracts were superior to the ethanolic crude extracts. Also, chloroform crude extracts of sponge inhibited the growth of all bacterial pathogens.

The antibacterial and anticandidal activities of sponges collected from the southern part of the Gulf of Aqaba were investigated. Methanol extracts of 10 sponge species were tested against 6 test microorganisms: Gram-positive bacteria, Bacillus subtilis, and Staphylococcus aureus; the Gramnegative bacteria: Escherichia coli and Proteus vulgaris and the yeasts Candida albicans and C. tropicalis. Three species only named Acanthella carteri, Ircinia felix, and Ircinia strobilinia had broad spectrum antimicrobial activity. On the other hand, growth promotion was stimulated by Ircinia felix towards Escherichia coli. Investigating different bioactivity of sponges may open new avenues for introducing novel marine compounds into pharmaceutical industry. Also, screening the inhibitory or promoting activities of sponge extracts may reflect the ecological mechanisms of fouling organisms settled on the sponge substratum (Gab-All et al. 2000).

Dhinakaran and Lipton (2012) tested the crude methanolic extracts of the sponge Sigmadocia pumila collected from kanyakumari region for antibacterial activity. Their extracts were tested against Gram positive and Gram negative organisms. The antifungal activity was examined against various fungal strains such as Trichoderma viride, Fuzarium spp., Aspergillus niger, Candida albicans, Penicillium chrysogenum, and Aspergillus flavis. Hence, it is assumed that the sponge exhibited high antimicrobial activities.

In the present investigation, extract of $C$. crassa showed an antioxidant activity with value of $671 \mu \mathrm{g} / \mathrm{ml}$ as IC50. Phytochemicals present in sponges can act as antioxidants and prevent disorders due to oxidative damage (Mannix et al. 1999). Shaaban et al. (2012) collected four marine sponges: Smenospongia, Callyspongia, Niphates, and Stylissa from the Red Sea at Egyptian coasts, and taxonomically characterized. The sponges' extracts exhibited diverse inhibitory effects on oxidative stress indices and carbohydrate hydrolyzing enzymes in linear relationships to some extent with concentration of inhibitors (dose dependant). The extracts of sponges (3, 1, and 2) showed, respectively, potent-reducing power.

Seradj et al. (2012) compounds especially from natural sources are capable of protecting against reactive oxygen species (ROS)-mediated damage. Therefore, there is a growing interest in novel substances exhibiting antioxidant properties. Several marine environments can provide a rich source of novel biologically active compounds. They evaluated the effects of different concentrations of the dichloromethane and methanolic extracts of six sponges on scavenging DPPH and $\mathrm{OH}$ free radicals. The activities of these extracts were compared with those of commercial antioxidants such as gallic acid. The maximum level of $\mathrm{DPPH}$ radical scavenging $(0.234 \pm 0.033 \mathrm{mg} / \mathrm{ml})$ was observed for the methanolic extract of Pseudosaberites clavatus in the reaction mixture. Also, most of sponge extracts exhibited medium to high hydroxyl radical scavenging activity. The results of this study suggest that marine sponges of the Persian Gulf are promising sources of antioxidants.

Herein, there was only one extract that had antiinflammatory activity; it was of C. crassa (61.47\%). Youssef et al. (2010) found that bioassay-guided fractionation of the anti-inflammation fractions of the Red Sea sponges Scalarispongia aqabaensis and Callyspongia siphonella yielded two new sterols from chloroform fractions of methanol extracts, namely, scalaristerol (5a,8adihydroxycholest-6-en-3ß-ol) (1) from Scalarispongia aqabaensis and callysterol (ergosta-5,11-dien-3ß-ol) (2) from Callyspongia siphonella. They indicated that compound 2 has a strong anti-inflammatory activity, which is close to that of cortisone, while compound 1 showed moderate anti- 
inflammatory activity. On the other hand, Mayer et al. (2005) conducted a structure-activity relationship study to investigate the antineuroinflammatory properties of the in dole-derived alkaloids manzamines isolated from the marine sponges: Haliclona sp., Amphimedon sp., and Xestospongia sp.

In this context, Busserolles et al. (2005) tested the hypothesis that oral administration of two marine terpenes isolated from the sponges Dysidea sp. and Petrosaspongia nigra, could inhibit inflammation and oxidative stress in an in vivo murine model of inflammatory bowel disease in humans. The observation that both compounds inhibited neutrophilic infiltration, interleukin-1ß, prostaglandin $\mathrm{E}$ levels, and cyclooxygenase 2 protein expression in vivo, supports further development of these compounds for "protective strategies" against intestinal inflammatory diseases.

\section{Conclusions}

1- The crude extract of $C$. siphonella showed high antitumor activity against colon cancer (caco-2) and breast cancer (Mcf-7) on cell line.

2- The C. crassa extract showed high cytotoxic effect to Vero cell with HAV.

3- The most effective extract was of $C$. crassa against Escherichia coli, Pseudomonas aeruginosa, and Candida albicans.

4- The ethanolic crude of $C$. siphonella showed positive antibacterial activity against $P$. aueroginosa.

5- The C. crassa extract conducted an antioxidant activity in corresponding to ascorbic acid standard with value of $671 \mu \mathrm{g} / \mathrm{ml}$ as IC50.

6- The C. crassa crude extract had anti-inflammatory activity.

7- The ethanolic crude extract of C. siphonella conducted to promising antitumor agent and $C$. crassa conducted to promising anti-inflammatory and antiviral agents.

\section{Abbreviations}

AU: Absolute unit; BSA: Bovine serum albumin; caco-2: Colon cancer; CPE: Cytopathic effect; DMEM: Dulbecco's modified Eagle's medium; DPPH: 2, 2-diphenyl-1-picrylhydrazyl; HAV: Hepatitis A virus; HSV-1: Herpes simplex type 1; HSV-1: Herpes simplex virus type; IC50: Inhibitor concentration; MAPKs: Mitogen-activated protein kinases; Mcf-7: Breast cancer; NFkappaB: The nuclear factor kappaB; PI: The percentage inhibition

\section{Acknowledgements}

The authors are deeply thankful to Dr. W. Bakry for his help in some practical work and his unlimited support.

\section{Funding}

No funding

\section{Authors' contributions}

HAHI is the principal investigator of the research work, who is responsible for making the main work of extract preparation and antimicrobial assay. HE-N is the main investigator who collected and identified the sponge species and studied the whole biological and ecological parts of the obtained sponges. KE-
$D$ is the main investigator responsible for points of research in the manuscript and revision of manuscript. MAEB is the main investigator who participated in the whole of practical works, additionally, he wrote some parts of the manuscript. FMAS is responsible for points of research in the manuscript, in addition to controlling the whole manuscript research points. All authors read and approved the final manuscript.

Ethics approval and consent to participate

Not applicable

\section{Consent for publication}

Not applicable

\section{Competing interests}

The authors declare that they have no competing interests.

\section{Publisher's Note}

Springer Nature remains neutral with regard to jurisdictional claims in published maps and institutional affiliations.

\section{Author details}

${ }^{1}$ National Institute of Oceanography and Fisheries, Alexandria branch, Alexandria, Egypt. ${ }^{2}$ Faculty of Science, Al-Azhar University, Cairo, Egypt.

Received: 16 May 2017 Accepted: 23 November 2017

Published online: 15 December 2017

\section{References}

Abou-Elela, G. M., Abd-Elnaby, H., Ibrahim, H. A. H., \& Okbah, M. A. (2009). Marine natural products and their potential applications as anti-infective agents. World Applied Science Journal, 7(7), 872-880.

Atlas, R. M. (1997). Handbook of media for environmental microbiology: 265-412. Boca Raton: CR Press.

Ballantine, D. L., Gerwick, W. H., Velez, S. M., Alexander, E., \& Guevara, P. (1987). Antibiotic activity of lipid-soluble extracts from Caribbean marine algae. Hydrobiologia, 151/152, 463-469

Blunt, J. W., Copp, B. R., Munro, M. H. G., Northcote, P. T., \& Prinsep, M. R. (2005), Marine natural products. Natural Product Reports, 22, 16-61.

Busserolles, J., Paya, M., D'Auria, M. V., Gomez-Paloma, L., \& Alcaraz, M. J. (2005). Protection against 2,4,6-trinitrobenzenesulphonic acid-induced colonic inflammation in mice by the marine products bolinaquinone and petrosaspongiolide M. Biochemical Pharmacology, 69, 1433-1440.

De-Silva, E. D., \& Scheuer, P. J. (1980). Manoalide, an antibiotic sesterterpenoid from the marine sponge Luffariella variabilis (Polejaeff). Tetrahedron Letters, $21,1611-1612$

Dhinakaran, D. I., \& Lipton, A. P. (2012). Antimicrobial potential of the marine sponge Sigmadocia pumila from the south eastern region of India. World Journal of Fish and Marine Sciences, 4(4), 344-348.

Donia, M., \& Hamann, M. T. (2003). Marine natural products and their potential applications as anti-infective agents. Lancet. Infectious Diseases, 3(6), 338-348.

El-Sayed, K. A., Hamann, M. T., Hashish, N. E., Shier, W. T., Kelly, M., \& Khan, A. A. (2001). Antimalarial, antiviral, and antitoxoplasmosis norsesterterpene peroxide acids from the Red Sea sponge Diacarnus erythraeanus. Journal of Natural Products, 64(4), 522-524.

Faulkner, D. J. (2000). Marine natural products. Natural Product Reports, 17, 7-55.

Faulkner, D. J. (2002). Marine natural products. Natural Product Reports, 19, 1-48.

Gab-All, A. A. F. A., Kilada, R. W., Shalaby, I. M., \& Helmy, T. (2000). Antimicrobial activity of some sponges from the Gulf of Aqaba. Egyptian Journal of Biology, 2, 28-33.

Gunasekera, S. P., Gunasekera, M., Longley, R. E., \& Schulte, G. K. (1990). Discodermolide: a new bioactive polyhydroxylated lactone from the marine sponge Discodermia dissolute. The Journal of Organic Chemistry, 55, 4912-4915.

Guyot, M. (2000). Intricate aspects of sponge chemistry. Zoosystema, 22, 419-431.

Hooper, J.N.A., Van Soest, R.W.M., 2002. In Systema Porifera. A guide to the classification of sponges (2, p. 1708). New York: Kluwer Academic/Plenum Publishers.

Ilan, M., Gugel, J., \& Van Soest, R. W. M. (2004). Taxonomy, reproduction and ecology of new and known Red Sea sponges. Sarsia, 89, 388-410.

Isbrucker, R. A., Cummins, J., Pomponi, S. A., Longley, R. E., \& Wright, A. E. (2003). Tubulin polymerizing activity of dictyostatin-1, a polyketide of marine sponge origin. Biochemical Pharmacology, 66(1), 75-82. 
Kelman, D., Kashman, Y., Rosenberg, E., Ilan, M., Ifrach, I., \& Loya, Y. (2000). Antimicrobial activity of the reef sponge Amphimedon viridis from the Red Sea. Aquatic Microbial Ecology, 24, 9-16

Kohn, L. K., Porto, P. S. S., Bianchi, B. R. C., Santos, M. F. C., \& Berlinck, R. G. S. (2012). NOR-Batzelladine $L$ from the sponge Monanchora sp. displays antiviral activity against Herpes Simplex virus type 1. Planta Medica, 78, CL27.

Lee, O., \& Qian, P. Y. (2003). Chemical control of bacterial epibiosis and larval settlement of Hydroides elegans in the red sponge Mycale Adherens. Biofouling, 19, 171-180.

Mannix, D., Langridge, S., Lander, G. H., Rebizant, J., Longfield, M. J., \& Stirling, W. G. L. (1999). Experiments on transuranium compounds with X-ray resonant exchanges cattering. Physical B, Physical Condensed Matter, 262, 125-140.

Mayer, A. M. S., Hall, M. L., Lynch, S. M., Gunasekera, S. P., Sennett, S. H., \& Pomponi, S. A. (2005). Differential modulation of microglia superoxide anion and thromboxane $\mathrm{B} 2$ generation by the marine manzamines. BMC Pharmacology, 5(6), 22-34.

Mayer, A. M. S., \& Hamann, M. T. (2005). Marine pharmacology in 2001-2002: Marine compounds with anthelmintic, antibacterial, anticoagulant antidiabetic, antifungal, anti-inflammatory antimalarial, antiplatelet, antiprotozoal, antituberculosis and antiviral activities; affecting the cardiovascular, immune and nervous systems and other miscellaneous mechanisms of action. Comparative Biochemistry and Physiology, 140, 21

Perdicaris, S., Vlachogianni, T., \& Valavanidis, A. (2013). Bioactive natural substances from marine sponges: new developments and prospects for future pharmaceuticals. Natural Products Chemistry and Research, 1(3), 3-8.

Privat, D., Garilke, M., \& Rudder, J. D. (1964). Effect de deux nucleosides de l'arabinosesurla multiplication de virus l'herpeset de la vaccine en culture cellulaire. Comptes Rendus de l'Académie des Sciences [D] (Paris), 259, 2725-2728.

Rabelo, L., Monteiro, N., Serquiz, R., Santos, P., \& Oliveira, R. (2012). A lactosebinding lectin from the marine sponge Cinachyrella apion (cal) induces cell death in human cervical adenocarcinoma cells. Marine Drugs, 10, 727-743.

Rao, J. V., Usman, P. K., \& Kumar, J. B. (2008). Larvicidal and insecticidal properties of some marine sponges collected in Palk Bay and Gulf of Mannar waters. African Journal of Biotechnology, 7(2), 109-113.

Richter, G. (1907). Wer hat zuerst die Spongiaustagegen den Kropfempfohlen? Arch Klin. Chirurgie, 82, 952.

Rodriguez-Nieto, S., Gonzalez-Iriarte, M., Carmona, R., Munoz-Chapuli, R., Medina, M. A. \& Quesada, A. R. (2002). Antiangiogenic activity of aeroplysinin-1, a brominated compound isolated from a marine sponge. F.A.S.E.B Journal, 16(2), 261-263.

Saintigny, P., Zhang, L., Fan, Y. H., El-Naggar, A. K., Papadimitrakopoulou, V. A., \& Feng, L. (2011). Gene expression profiling predicts the development of oral cancer. Cancer Prevention Research (Phila), 4, 218-229.

Sakat, S., Juvekar, A. R., \& Gambhire, M. N. (2010). In vitro antioxidant and antiinflammatory activity of methanol extract of Oxalis Corniculata. African Journal of Biotechnology, 5(4), 1109-1113.

Santiago, B. J. C., Konecny, K. L., Fantinatti-Garboggini, F., Aiello, P. M., \& Furtado, F. E. (2013). Antiviral activity of bacillus sp. isolated from the marine sponge Petromica citrina against bovine viral diarrhea virus a surrogate model of the hepatitis C virus. Virus, 5, 1219-1230.

Seradj, H., Moein, M., Eskandari, M., \& Maaref, F. (2012). Antioxidant activity of six marine sponges collected from the Persian Gulf. Iranian Journal of Pharmaceutical Research, 8(4), 249-255.

Shaaban, M., Abd-Alla, H., Hassan, A. Z., Aly, H. F., \& Ghani, M. A. (2012). Chemical characterization, antioxidant and inhibitory effects of some marine sponges against carbohydrate metabolizing enzymes. Organic and Medicinal Chemistry Letters, 2, 30

Sharma, G. M., Vig, B., \& Burkholder, P. R. (1970). In H. W. Youngken (Ed.), In food drugs from the sea, (p. 307). Washington, D.C: The Marine Technology Society.

Sipkema, D., Franssen, M. C., Osinga, R., Tramper, J., \& Wijffels, R. H. (2005). Marine sponges as pharmacy. Marine Biotechnology (NY), 7, 142-162.

Somnath, C., \& Ghosh, U. (2010). Oceans: a store house of drugs - a review. Journal of Pharmacy Research, 3, 4.

Valeriote, F. A., Tenney, K., Media, J., Pietraszkiewicz, H., \& Edelstein, M. (2012). Discovery and development of anticancer agents from marine sponges: perspectives based on a chemistry-experimental therapeutics collaborative program. Journal of experimental therapeutics and. Oncology, 10, 119-134.

Van Soest, R.W.M., Boury-Esnault, N., Hooper, J.N.A., Rützler, K., de Voogd, N.J., Alvarez de Glasby, B., Hajdu, E., Pisera, A.B., Vacelet, J., Manconi, R., Schoenberg, C., Janussen, D., Tabachnick, K.R., Klautau, M., Picton, B., Kelly, M., 2008. World Porifera database. http://www.marinespecies.org (porifera)
Villa, F. A., \& Gerwick, L. (2010). Marine natural product drug discovery: leads for treatment of inflammation, cancer, infections, and neurological disorders. Immunopharmacology and Immunotoxicology, 32, 228-237.

Wah, L. K., Jhaumeer-Laulloo, S., Yive, R. C. K., Bonnard, I., \& Banaigs, B. (2006). Biological and chemical study of some soft corals and sponges collected in Mauritian waters. Western Indian Ocean Journal of Marine Science, 5, 115-121.

Yang, R., Johnson, M. C., \& Ray, B. (1992). Novel method to extract large amounts of bacteriocins from lactic acid bacteria. Applied and Environmental Microbiology, 58(10), 3355-3359.

Yasumura, Y., \& Kawakita, Y. (1963). Studies on SV40 in tissue culture-preliminary step for cancer research in vitro. Nihon Risnsho, 21, 1201-1215.

Yen, G. C., \& Duh, P. D. (1994). Scavenging effect of methanolic extracts of peanut hulls on free-radical and active-oxygen species. Journal of Agricultural and Food Chemistry, 42(3), 629-632.

Youssef, D. T. A., Ibrahim, A. K., Khalifa, S. I., Mesbah, M. K., Mayer, A. M. S., \& van Soest, R. W. M. (2010). New anti-inflammatory sterols from the Red Sea sponges Scalarispongia agabaensis and Callyspongia siphonella. Natural Product Communications, 5(1), 27-31.

\section{Submit your manuscript to a SpringerOpen ${ }^{\circ}$ journal and benefit from:}

- Convenient online submission

- Rigorous peer review

- Open access: articles freely available online

- High visibility within the field

- Retaining the copyright to your article

Submit your next manuscript at springeropen.com 